\title{
Article \\ Highly Efficient and Ambient-Temperature Synthesis of Benzimidazoles via Co(III)/Co(II)-Mediated Redox Catalysis
}

\author{
Renyuan Zhong, Wulin Xiong, Haoyuan Zhang, Tongtong Zeng, Shanshan Gong * and Qi Sun *(i) \\ Jiangxi Key Laboratory of Organic Chemistry, Jiangxi Science and Technology Normal University, \\ 605 Fenglin Avenue, Nanchang 330013, China; zhongrenyuan1@126.com (R.Z.); xiongwulin1@126.com (W.X.); \\ zhanghaoyuan10@126.com (H.Z.); zengtongtong1@126.com (T.Z.) \\ * Correspondence: gongshanshan@jxstnu.edu.cn (S.G.); sunqi@jxstnu.edu.cn (Q.S.)
}

Citation: Zhong, R.; Xiong, W.; Zhang, H.; Zeng, T.; Gong, S.; Sun, Q. Highly Efficient and AmbientTemperature Synthesis of Benzimidazoles via Co(III)/Co(II)Mediated Redox Catalysis. Catalysts 2022, 12, 59. https://doi.org/ 10.3390/catal12010059

Academic Editor: Gianluigi Albano

Received: 7 December 2021

Accepted: 2 January 2022

Published: 5 January 2022

Publisher's Note: MDPI stays neutral with regard to jurisdictional claims in published maps and institutional affiliations.

Copyright: (C) 2022 by the authors. Licensee MDPI, Basel, Switzerland. This article is an open access article distributed under the terms and conditions of the Creative Commons Attribution (CC BY) license (https:// creativecommons.org/licenses/by/ $4.0 /)$.
Abstract: An efficient method for ambient-temperature synthesis of a variety of 2-substituted and 1,2disubstituted benzimidazoles from aldehyde and phenylenediamine substrates has been developed by utilizing $\mathrm{Co}(\mathrm{III}) / \mathrm{Co}(\mathrm{II})$-mediated redox catalysis. The combination of only $1 \mathrm{~mol} \%$ of $\mathrm{Co}(\mathrm{acac})_{2}$ and stoichiometric amount of hydrogen peroxide provides a fast, green, and mild access to a diversity of benzimidazoles under solvent-free conditions.

Keywords: benzimidazole; $\mathrm{Co}(\mathrm{acac})_{2}$; redox catalysis; oxidative dehydrogenation; multivalent transition metal catalyst

\section{Introduction}

Benzimidazole is the key skeleton of a great variety of pharmaceutical agents [1] and functional materials [2]. In the past few decades, many substituted benzimidazoles have been prepared and exhibited a broad spectrum of pharmacological activities [3-6]. Moreover, the antifungal activities of many benzimidazole derivatives against phytopathogenic fungi have further extended their applications in agriculture [7,8]. Therefore, a huge amount of work has been dedicated to the development of novel synthetic methods for benzimidazoles. Among the various approaches, cyclization of $o$-aminoaniline and aldehyde is the most commonly employed method due to its excellent starting material availability. The well-accepted reaction pathway involves sequential condensation, cycloaddition, and oxidative dehydrogenation [9-11]. Previous research on catalysis based on Lewis acids, such as $\mathrm{Sc}(\mathrm{OTf})_{3}$ [12], $\mathrm{ZrOCl}_{2}$ [13], $\mathrm{Y}(\mathrm{OTf})_{3}$ [14], $\mathrm{ZnCl}_{2}$ [15], $\mathrm{Co}(\mathrm{OH})_{2}$ [16], $\mathrm{Ce}\left(\mathrm{NO}_{3}\right)_{3}$ [17], $\mathrm{InCl}_{3}$ [18], $\mathrm{HfCl}_{4}$ [19], and montmorillonite $\mathrm{K} 10$ [20], and deep eutectic solvents (DESs) [21] shows that these methods typically need heating (over $80^{\circ} \mathrm{C}$ ) and long reaction time (at least several hours) for oxidation of benzimidazoline intermediate by atmospheric oxygen. In contrast, the catalytic approaches based on oxidants including oxone [22], 1,4-benzoquinone [23], iodobenzene diacetate [24], $\mathrm{I}_{2}$ [25], $\mathrm{MnO}_{2}$ [26], $\mathrm{I}_{2} / \mathrm{UHP}$ [27], and $\left(\mathrm{NH}_{4}\right)_{2} \mathrm{Ce}\left(\mathrm{NO}_{3}\right)_{6} / \mathrm{H}_{2} \mathrm{O}_{2}$ [28] could proceed at faster reaction rate (several minutes to a few hours) under milder conditions (RT to $50^{\circ} \mathrm{C}$ ), showing that oxidative dehydrogenation is the rate-determining step. In addition, functionalized dendrimers [29], mesoporous materials [30], and nanoparticles [31-33] have also emerged as new effective catalysts for benzimidazole synthesis. However, the poor availability of these specifically prepared catalysts greatly limited their applications.

Recently, our research group rationally constructed a novel phosphomolybdic acid (PMA)-based catalytic system for benzimidazole synthesis at ambient temperature [34] Compared to the conventional oxidative methods, insertion of the $\mathrm{Mo}(\mathrm{VI}) / \mathrm{Mo}(\mathrm{V})$ redox cycle between reductive benzimidazoline and oxidative tert-butyl hydroperoxide (TBHP) dramatically accelerated the oxidative dehydrogenation process. Inspired by this method, we further explored the possibility to utilize small molecular multivalent transition metal complexes to catalyze oxidative dehydrogenation. In the paper, we report the development 
of a $\mathrm{Co}(\mathrm{acac})_{2}$-based redox catalytic system for fast, green, and mild synthesis of a variety of substituted benzimidazoles.

\section{Results and Discussion}

In our initial attempt, $\mathrm{MoO}_{2}$ (acac) 2 was selected as a multivalent transition metal catalyst to replace PMA Keggin cluster in our previously reported redox catalytic system. The reaction of 1.05 equiv of benzaldehyde, 1 equiv of $N$-phenyl-o-phenylenediamine, $1 \mathrm{~mol} \%$ of $\mathrm{MoO}_{2}(\mathrm{acac})_{2}$, and 1.2 equiv of TBHP (5.5 $\mathrm{M}$ in decane) in DMSO yielded the target benzimidazole 1 in $72 \%$ yield over $2.5 \mathrm{~h}$ without heating. The experimental result proved the possibility to replace large polyoxometalate (POM) cluster catalyst with a small molecular multivalent transition metal complex to catalyze the oxidative dehydrogenation of benzimidazoline. However, it should be noted that the yield and reaction rate of 1 were lower than those of the PMA-mediated redox catalysis due to incomplete oxidation of intermediate. The solvent effects showed that the reaction proceeded much faster in EtOH and $\mathrm{CH}_{3} \mathrm{CN}$ (20-40 min), but the yields of 1 were similar to those in DMSO, THF, and DME. Interestingly, solvent-free conditions significantly promoted the consumption of benzimidazoline intermediate and afforded 1 in 90\% yield within 15 min (Table 1). It was observed that the originally yellow-colored reaction mixture of aldehyde and diamine turned green upon addition of $\mathrm{MoO}_{2}(\mathrm{acac})_{2}$, indicating that $\mathrm{Mo}(\mathrm{VI})$ quickly oxidized benzimidazoline and was reduced to blue-colored $\mathrm{Mo}(\mathrm{V})$ species. Upon addition of TBHP, $\mathrm{Mo}(\mathrm{V})$ was almost instantly oxidized back to $\mathrm{Mo}(\mathrm{VI})$ species to complete the redox cycle. The fact that Mo catalyst existed as yellow-colored Mo(VI) state during the reaction process implied that the rate-determining step in the redox cycle was the oxidative dehydrogenation of benzimidazoline by $\mathrm{Mo}(\mathrm{VI})$.

Table 1. Solvent effects on $\mathrm{MoO}_{2}(\mathrm{acac})_{2}$-catalyzed synthesis of $\mathbf{1}^{1}$.

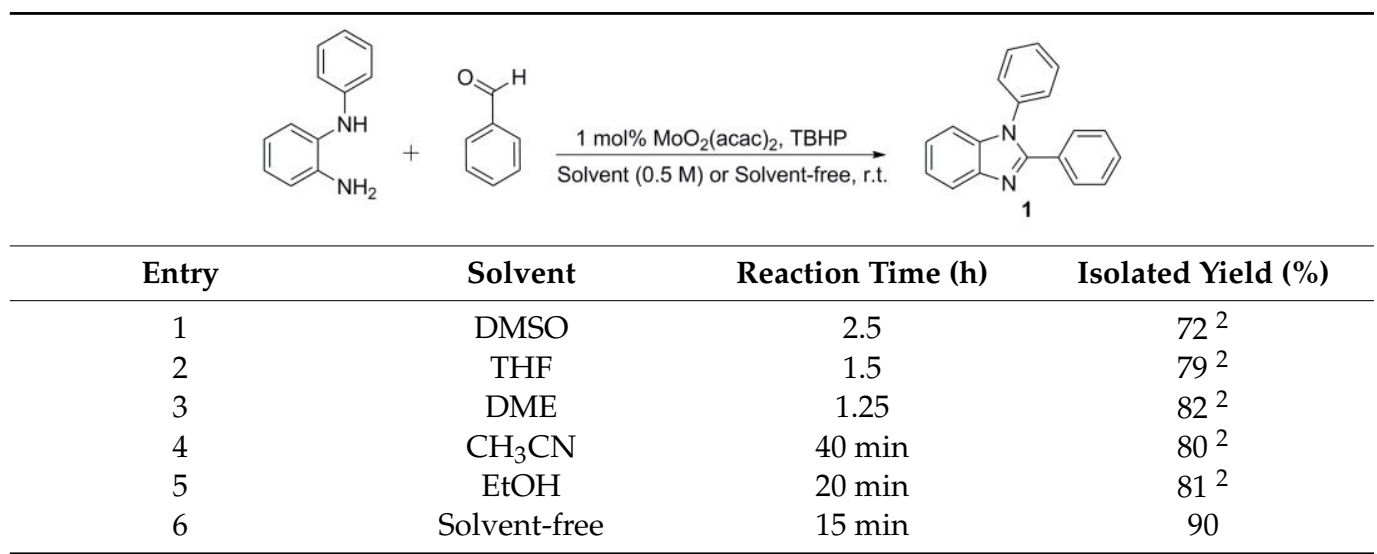

1 The reactions were performed with $1.05 \mathrm{mmol}$ of benzaldehyde, $1.0 \mathrm{mmol}$ of $\mathrm{N}$-phenyl-o-phenyl- enediamine $0.01 \mathrm{mmol}$ of $\mathrm{MoO}_{2}$ (acac) $)_{2}$, and $1.2 \mathrm{mmol}$ TBHP (5.5 M in decane) in $2 \mathrm{~mL}$ of solvent or under solvent-free conditions. $\left(\mathrm{MoO}_{2}(\mathrm{acac})_{2}\right.$ was soluble in all the organic solvents tested). ${ }^{2}$ Benzimidazoline intermediate was not completely consumed when the reaction stopped.

On the basis of the solvent-free conditions, we tested the catalytic efficacy of acetylacetonates of different multivalent transition metals. The experimental results listed in Table 2 showed that $\mathrm{Ni}(\text { acac })_{2}$ and $\mathrm{Cu}(\text { acac })_{2}$ were less effective than $\mathrm{MoO}_{2}(\text { acac })_{2}$. $\mathrm{VO}(\mathrm{acac})_{2}$ showed similar effect to $\mathrm{MoO}_{2}(\mathrm{acac})_{2}$, whereas $\mathrm{Fe}(\mathrm{acac})_{3}, \mathrm{Ce}(\mathrm{acac})_{3}, \mathrm{Co}(\mathrm{acac})_{2}$, and $\mathrm{Co}(\text { acac })_{3}$ exhibited better reactivity than $\mathrm{MoO}_{2}(\text { acac })_{2}$. The $\mathrm{Cu}(\text { acac })_{2}$-catalyzed reaction was ultrafast and finished in only $2 \mathrm{~min}$. After TBHP was added, the reaction mixture turned black immediately and resulted in lowered yield. This is possibly because the complexation of $\mathrm{Cu}(\mathrm{II})$ with $N$-phenyl-o-phenylenediamine promoted its oxidation. Generally, the catalytic activities of the other metal acetylacetonates are in accordance with the oxidation potentials of their high-valent metal ions with the exception of $\mathrm{Ni}(\mathrm{acac})_{2}$. The fact that the catalytic activities of the acetylacetonates of $\mathrm{Co}$ (II) and $\mathrm{Co}$ (III) are identical implied that the oxidation of $\mathrm{Co}(\mathrm{II})$ by TBHP should be very fast. Furthermore, other 
cobalt(II) salts, including $\mathrm{CoCl}_{2}$ and $\mathrm{Co}(\mathrm{OAc})_{2}$, were also tested for their catalytic activity. The experimental results indicated that $\mathrm{Co}(\mathrm{acac})_{2}$ is the most efficient catalyst with a TOF value of no less than $1164 \mathrm{~h}^{-1}$, while the real TOF value based on kinetic experiment was not established and could be even higher. Finally, a control experiment without multivalent transition metal catalyst confirmed their roles in promoting the formation of $\mathbf{1}$.

Table 2. The effects of multivalent transition metal catalysts on synthesis of $\mathbf{1}^{1}$.

\begin{tabular}{|c|c|c|c|}
\hline Entry & Catalyst & Reaction Time (min) & Isolated Yield (\%) \\
\hline 1 & $\mathrm{Cu}(\mathrm{acac})_{2}$ & 2 & 78 \\
\hline 2 & $\mathrm{Ni}(\text { acac })_{2}$ & 30 & 87 \\
\hline 3 & $\mathrm{MoO}_{2}(\text { acac })_{2}$ & 15 & 90 \\
\hline 4 & $\mathrm{VO}(\text { acac })_{2}$ & 15 & 89 \\
\hline 5 & $\mathrm{Fe}(\mathrm{acac})_{3}$ & 10 & 91 \\
\hline 6 & $\mathrm{Ce}(\text { acac })_{3}$ & 10 & 92 \\
\hline 7 & $\mathrm{Co}(\text { acac })_{3}$ & 7 & 97 \\
\hline 8 & $\mathrm{Co}(\mathrm{acac})_{2}$ & 7 & 97 \\
\hline 9 & $\mathrm{Co}(\mathrm{OAc})_{2}$ & 10 & 92 \\
\hline 10 & $\mathrm{CoCl}_{2}$ & 15 & 90 \\
\hline 11 & No catalyst & 360 & 82 \\
\hline
\end{tabular}

1 The reaction was performed with $1.05 \mathrm{mmol}$ of benzaldehyde, $1.0 \mathrm{mmol}$ of $\mathrm{N}$-phenyl-o-phenylene diamine $0.01 \mathrm{mmol}$ of catalyst or no catalyst, and $1.2 \mathrm{mmol}$ TBHP (5.5 $\mathrm{M}$ in decane) under solvent-free conditions. (Upon mixing of reactants, transparent and homogeneous mixtures were obtained)

In the following research, the effects of various peroxide oxidants were tested and listed in Table 3. The experimental results showed that more oxidative aqueous $\mathrm{H}_{2} \mathrm{O}_{2}$ resulted in a faster reaction rate. While the reactions with aqueous TBHP and urea hydrogen peroxide (UHP) proceeded slower, the reaction employing $m \mathrm{CPBA}$ finished in $5 \mathrm{~min}$ but yielded a significant amount of reddish polar byproducts on TLC plate. In addition, the experimental data also showed that $2 \mathrm{~mol} \% \mathrm{Co}(\mathrm{acac})_{2}$ resulted in more pronounced oxidation of $\mathrm{N}$ phenyl-o-phenylenediamine and lowered yield of 1 , whereas $0.5 \mathrm{~mol} \% \mathrm{Co}(\mathrm{acac})_{2}$ led to prolonged reaction time and decreased TOF. The control experiment showed that the oxidation of benzimidazoline was drastically impeded when $\mathrm{H}_{2} \mathrm{O}_{2}$ was replaced with atmospheric oxygen.

With optimized reaction conditions, we examined the substrate scope of the $\mathrm{Co}(\mathrm{III}) / \mathrm{Co}(\mathrm{II})-$ mediated redox catalytic system. As shown in Table 4, this new method works well with both $o$-phenylenediamineand $N$-substituted $o$-phenylenediamines. It maintained high catalytic activity on various substituted benzaldehydes, heteroaryl aldehydes, and cinnamaldehydes. It is noteworthy that this method exhibited an excellent catalytic effect on nitro-containing substrates, which are known as poor substrates in previous reports. The current method afforded 1,2-disubstituted benzimidazoles 1-18 in 83-97\% yields over a period of $5 \mathrm{~min}-1 \mathrm{~h}$ at ambient temperature. The reactions with $o$-phenylenediamines generally took longer than those with $N$-substituted $o$-phenylenediamines. The 2 -substituted benzimidazoles 19-30 were isolated in $82-95 \%$ yields after $15 \mathrm{~min}-1.5 \mathrm{~h}$ reaction time. As reported in the literature [9-11,35], 1,2-disubstituted benzimidazole byproducts could also form when $o$-phenylenediamine was used. The $\mathrm{Co}(\mathrm{III}) / \mathrm{Co}(\mathrm{II})$-mediated redox method exhibited high selectivity on desired 2-substituted benzimidazoles over 1,2-disubstituted byproducts. The undesired byproduct was obtainedin $4 \%$ yield in the synthesis of $19(\sim 96 \%$ selectivity). In other 0 -phenylenediamine-based reactions, the amount of 1,2-disubstituted byproduct was neglectable. 
Table 3. The effects of peroxide oxidants and amounts of $\mathrm{Co}(\mathrm{acac})_{2}$ on synthesis of $\mathbf{1}^{1}$.

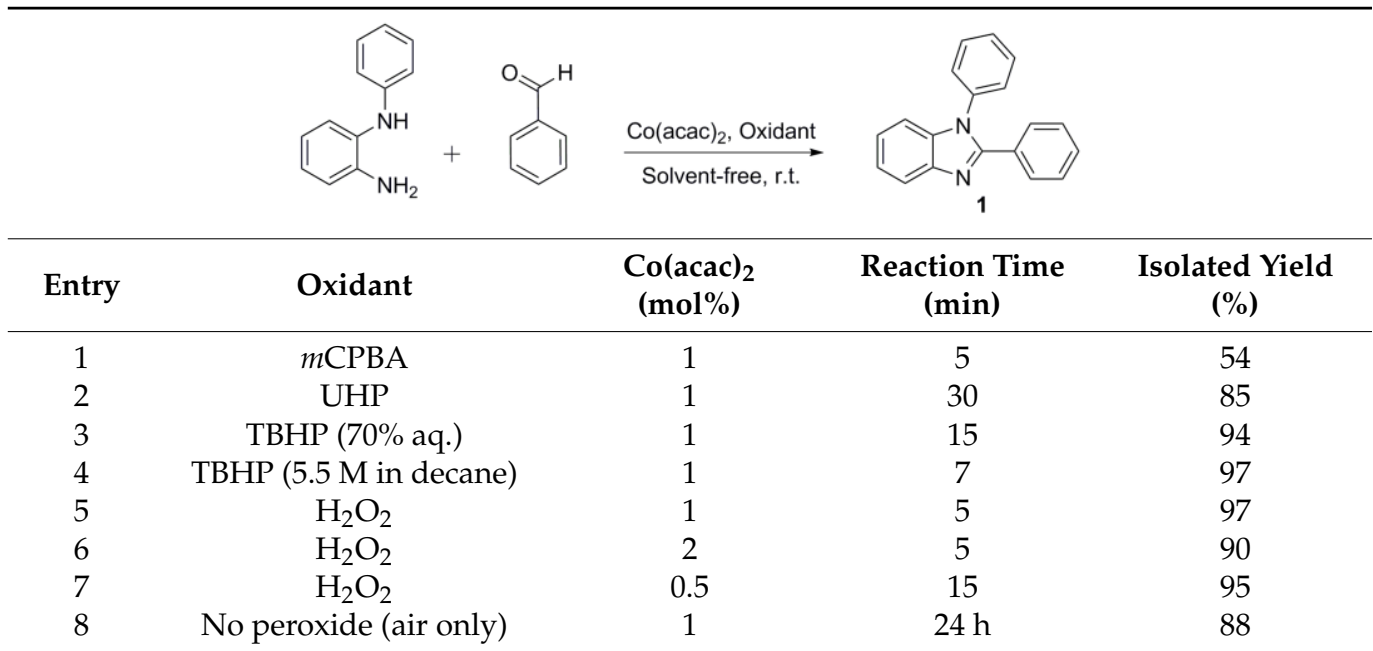

${ }^{1}$ The reaction was performed with $1.05 \mathrm{mmol}$ of benzaldehyde, $1.0 \mathrm{mmol}$ of $\mathrm{N}$-phenyl-o-phenyl- enediamine, 0.005-0.02 mmol of $\mathrm{Co}(\mathrm{acac})_{2}$, and $1.2 \mathrm{mmol}$ oxidant under solvent-free conditions. (Upon mixing of reactants, transparent and homogeneous mixtures were obtained).

Table 4. Synthesis of benzimidazoles (1-30) via Co(III)/Co(II)-mediated redox catalysis ${ }^{1}$.

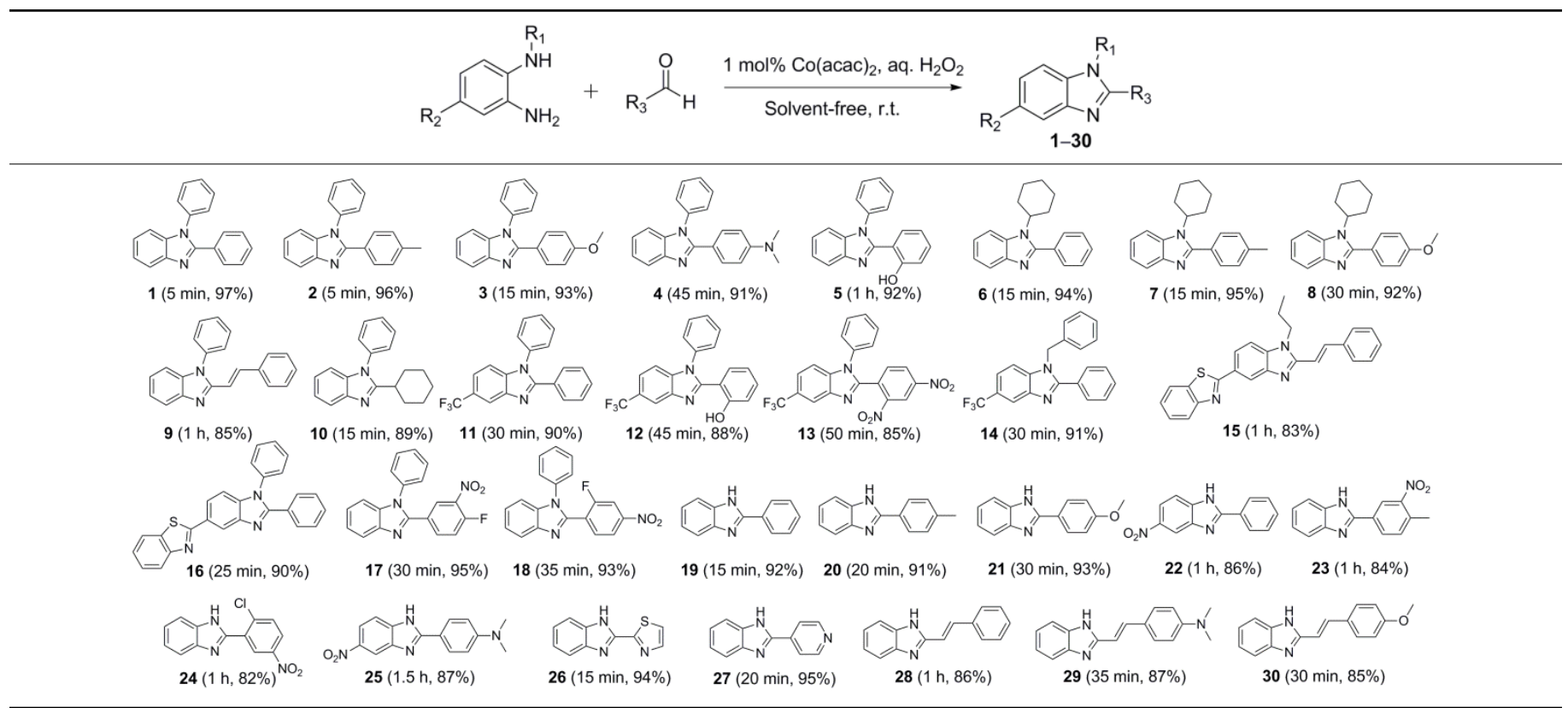

${ }^{1}$ The reaction was performed with $1.05 \mathrm{mmol}$ of benzaldehyde, $1.0 \mathrm{mmol}$ of $\mathrm{N}$-phenyl-o-phenylene diamine, $0.01 \mathrm{mmol}$ of $\mathrm{Co}(\mathrm{acac})_{2}$, and $1.2 \mathrm{mmol} \mathrm{H}_{2} \mathrm{O}_{2}(30 \%$ aq.) under solvent-free conditions.

As seen in Figure 1A, a Co(III)/Co(II) redox cycle-based reaction mechanism was proposed. Similar to what has been observed in our previous research on PMA/PMBmediated redox catalysis in DMSO [34], N-phenyl-o-phenylenediamine and benzaldehyde quickly formed yellow-colored imine and benzimidazoline intermediates upon mixing. Addition of green-colored $\mathrm{Co}(\mathrm{acac})_{3}$ converted the reaction mixture from yellow to green instantly. However, the green color faded quickly after $5 \mathrm{~s}$ and the reddish-yellow color remained until the end of the reaction. This result indicated that the green $\mathrm{Co}(\mathrm{III})$ quickly oxidized the benzimidazoline intermediate and was reduced to red-colored $\mathrm{Co}$ (II). A more apparent green-to-red color change was visualized on TLC plate (Figure 1B). The UV-Vis absorption data showed that the peak of Co(III) appeared at $\sim 600 \mathrm{~nm}$. Upon addition to the mixture of benzaldehyde and $\mathrm{N}$-phenyl-o-phenylenediamine, the green color faded quickly and the signal at $\sim 600 \mathrm{~nm}$ disappeared completely (Figure S1, SI). This result is 
in agreement with the color change observed both in glass vial and on TLC plate. In addition, the instant color change from red to green upon addition of aqueous $\mathrm{H}_{2} \mathrm{O}_{2}$ to a $\mathrm{CH}_{2} \mathrm{Cl}_{2}$ solution of $\mathrm{Co}(\mathrm{acac})_{2}$ proved that $\mathrm{H}_{2} \mathrm{O}_{2}$ is capable of oxidizing $\mathrm{Co}$ (II) back to $\mathrm{Co}$ (III) efficiently (Figure 1C). The fact that cobalt catalyst existed in red-colored $\mathrm{Co}$ (II) state during the reaction process indicated that the rate-limiting step in the redox cycle is the oxidative conversion of $\mathrm{Co}$ (II) to $\mathrm{Co}$ (III) by $\mathrm{H}_{2} \mathrm{O}_{2}$, which is different from the reaction with $\mathrm{MoO}_{2}(\mathrm{acac})_{2}$ and explains why $\mathrm{Co}(\mathrm{acac})_{2}$-based redox catalysis is faster than that based on $\mathrm{MoO}_{2}$ (acac) $)_{2}$.
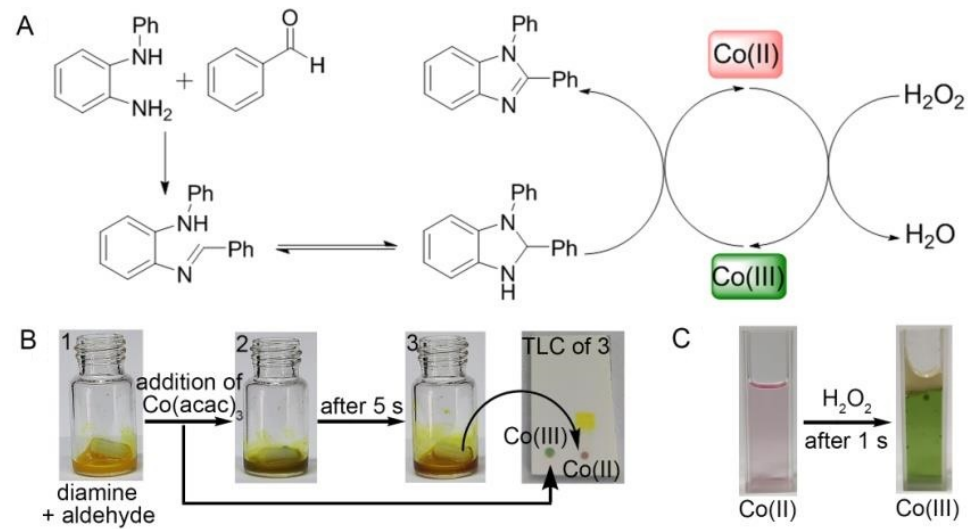

Figure 1. Mechanistic investigation. (A) Proposed redox catalysis mechanism, (B) color change upon addition of $1 \mathrm{~mol} \%$ of $\mathrm{Co}(\mathrm{acac})_{3}$ to the mixture of $1.05 \mathrm{mmol}$ of benzaldehyde and $1.0 \mathrm{mmol}$ of $\mathrm{N}$-phenyl-o-phenylenediamine under solvent-free conditions without peroxide, and (C) instant color change of $\mathrm{Co}$ (II) to $\mathrm{Co}$ (III) in $\mathrm{CH}_{2} \mathrm{Cl}_{2}\left(\mathrm{Co}(\mathrm{acac})_{2}, 4 \times 10^{-3} \mathrm{M}, 2 \mathrm{~mL}\right)$ upon addition of $\mathrm{H}_{2} \mathrm{O}_{2}(30 \%$ aq., $90 \mu \mathrm{L}, 100$ eq.).

\section{Materials and Methods}

\subsection{General Methods}

The solvents and chemical reagents used in the current research work were purchased from Leyan-Shanghai Haohong Scientific Co. Ltd., Shanghai, China. All of the reactions were monitored by TLC plates coated with $0.25 \mathrm{~mm}$ silica gel $60 \mathrm{~F}_{254}$ and visualized by $254 \mathrm{~nm}$ UV. The silica gel used in column chromatography (particle size 32-63 $\mu \mathrm{m}$ ) was purchased from Qingdao Haiyang Chemicals, Qingdao, China. ${ }^{1} \mathrm{H},{ }^{13} \mathrm{C}$, and ${ }^{19} \mathrm{~F}$ NMR spectra were recorded on an AV-400 instrument (Bruker BioSpin, Faellanden, Switzerland) with chemical shifts referenced to DMSO- $d_{6}$ or $\mathrm{CDCl}_{3}$ and reported in parts per million. Infrared spectra were obtained with a Vertex-70 instrument (Bruker Optics, Billerica, MA, USA). HRMS spectra were acquired with a micrOTOF-Q II instrument (Bruker Daltonics, Billerica, MA, USA) and reported as $m / z$. Melting points were measuredon an X-4 melting point apparatus and uncorrected (Tech Instrument, Beijing, China).

\subsection{General Synthetic Procedure and Characterization of Benzimidazoles}

To a mixture of $\mathrm{N}$-substituted $o$-phenylenediamine $/ o$-phenylenediamine $(1.0 \mathrm{mmol}$, 1.0 eq.), aldehyde ( $1.05 \mathrm{mmol}, 1.05$ eq. $)$, and $\mathrm{Co}(\mathrm{acac})_{2}(2.6 \mathrm{mg}, 0.01 \mathrm{mmol}, 0.01 \mathrm{eq}$.) in an open glass vial $(10 \mathrm{~mL})$ was added $30 \%$ aq. $\mathrm{H}_{2} \mathrm{O}_{2}(125 \mu \mathrm{L}, 1.2 \mathrm{mmol}, 1.2$ eq.) dropwise. The reaction mixture was stirred at $25{ }^{\circ} \mathrm{C}$ for $5 \mathrm{~min}-1.5 \mathrm{~h}$. Flash column chromatography on silicagel (PE/EA = 5:1) afforded products 1-30 in pure form. For larger-scale synthesis, dropwise slow addition of $30 \%$ aq. $\mathrm{H}_{2} \mathrm{O}_{2}$ and monitoring of reaction temperature are advised for safety precautions. The NMR spectra of new compounds are provided in the Supplementary Materials.

2-(1-Phenyl-5-(trifluoromethyl)-1H-benzo[d]imidazol-2-yl)phenol (12): a white solid, mp: 165$166{ }^{\circ} \mathrm{C} .{ }^{1} \mathrm{H}$ NMR $\left(400 \mathrm{MHz}, \mathrm{CDCl}_{3}\right): \delta 13.14(\mathrm{~s}, 1 \mathrm{H}), 8.07(\mathrm{~s}, 1 \mathrm{H}), 7.65-7.64(\mathrm{~m}, 3 \mathrm{H}), 7.49$ $(\mathrm{d}, J=8.5 \mathrm{~Hz}, 1 \mathrm{H}), 7.40(\mathrm{~m}, 2 \mathrm{H}), 7.23(\mathrm{t}, J=8.0 \mathrm{~Hz}, 1 \mathrm{H}), 7.15(\mathrm{~d}, J=8.5 \mathrm{~Hz}, 1 \mathrm{H}), 7.08(\mathrm{~d}$, $J=8.3 \mathrm{~Hz}, 1 \mathrm{H}), 6.84(\mathrm{~d}, J=8.1 \mathrm{~Hz}, 1 \mathrm{H}), 6.53\left(\mathrm{t}, J_{1}=J_{2}=8.0 \mathrm{~Hz}, 1 \mathrm{H}\right) \mathrm{ppm} ;{ }^{13} \mathrm{C} \mathrm{NMR}$ 
$\left(100 \mathrm{MHz}_{\mathrm{CDCl}}\right): \delta$ 160.0, 153.0, 139.8, 138.6, 132.2, $130.8(\times 2), 130.2,127.9(\times 2), 127.6$, $126.1(\mathrm{q}, J=32.1 \mathrm{~Hz}), 124.7(\mathrm{q}, J=270.3 \mathrm{~Hz}), 120.8,118.4,116.5,120.0,111.0 \mathrm{ppm} ;{ }^{19} \mathrm{~F}$ NMR $\left(470 \mathrm{MHz}, \mathrm{CDCl}_{3}\right): \delta-59.0 \mathrm{ppm}$; IR (KBr): $v_{\max } 3064,2926,2850,1877,1629,1582,1484$, $1443,1409,1378,1322,1255,1050,943,885,811,752 \mathrm{~cm}^{-1}$; HRMS (ESI+): $\mathrm{m} / z$ calcd for $\mathrm{C}_{20} \mathrm{H}_{14} \mathrm{~F}_{3} \mathrm{~N}_{2} \mathrm{O}[\mathrm{M}+\mathrm{H}]^{+}$355.1053; found 355.1052.

2-(2,4-Dinitrophenyl)-1-phenyl-5-(trifluoromethyl)-1H-benzo[d]imidazole (13): a white solid, mp: 195-196 ${ }^{\circ} \mathrm{C} .{ }^{1} \mathrm{H}$ NMR $\left(400 \mathrm{MHz}, \mathrm{CDCl}_{3}\right): \delta 8.78(\mathrm{~d}, J=2.2 \mathrm{~Hz}, 1 \mathrm{H}), 8.49\left(\mathrm{dd}, J_{1}=2.2 \mathrm{~Hz}\right.$, $\left.J_{2}=8.4 \mathrm{~Hz}, 1 \mathrm{H}\right), 8.17(\mathrm{~s}, 1 \mathrm{H}), 7.86(\mathrm{~d}, J=8.4 \mathrm{~Hz}, 1 \mathrm{H}), 7.61(\mathrm{~d}, J=8.6 \mathrm{~Hz}, 1 \mathrm{H}), 7.49-7.43$ $(\mathrm{m}, 4 \mathrm{H}), 7.27-7.23(\mathrm{~m}, 2 \mathrm{H}) \mathrm{ppm} ;{ }^{13} \mathrm{C} \mathrm{NMR}\left(100 \mathrm{MHz}, \mathrm{CDCl}_{3}\right): \delta 149.1,148.6,148.5,142.5$, $138.1,134.3,134.2,131.1,130.4(\times 2), 129.6,127.2,126.8(\times 2), 126.2(q, J=32.3 \mathrm{~Hz}), 124.4(q$, $J=270.4 \mathrm{~Hz}), 121.5(\mathrm{q}, J=3.4 \mathrm{~Hz}), 120.1,118.5(\mathrm{q}, J=4.1 \mathrm{~Hz}), 118.4,111.3 \mathrm{ppm} ;{ }^{19} \mathrm{~F}$ NMR $\left(470 \mathrm{MHz}, \mathrm{CDCl}_{3}\right): \delta-59.1$ ppm; IR (KBr): $v_{\max } 3105,3053,2923,2874,1912,1778,1616$, $1599,1537,1457,1437,1384,1348,1232,1167,1122,1049,922,825,770,710 \mathrm{~cm}^{-1}$; HRMS (ESI+): $m / z$ calcd for $\mathrm{C}_{20} \mathrm{H}_{12} \mathrm{~F}_{3} \mathrm{~N}_{4} \mathrm{O}_{4}[\mathrm{M}+\mathrm{H}]^{+} 429.0805$; found 429.0802 .

2-(1-Propyl-2-styryl-1H-benzo[d] imidazol-5-yl)benzo[d]thiazole (15): a white solid, mp: $166-167^{\circ} \mathrm{C}$. ${ }^{1} \mathrm{H}$ NMR $\left(400 \mathrm{MHz}, \mathrm{CDCl}_{3}\right): \delta 8.41(\mathrm{~s}, 1 \mathrm{H}), 8.12(\mathrm{~d}, J=8.5 \mathrm{~Hz}, 1 \mathrm{H}), 8.10-8.00(\mathrm{~m}, 2 \mathrm{H}), 7.88$ $(\mathrm{d}, J=7.9 \mathrm{~Hz}, 1 \mathrm{H}), 7.61(\mathrm{~d}, J=7.4 \mathrm{~Hz}, 2 \mathrm{H}), 7.47(\mathrm{t}, J=7.7 \mathrm{~Hz}, 1 \mathrm{H}), 7.44-7.32(\mathrm{~m}, 5 \mathrm{H}), 7.03(\mathrm{~d}$, $J=15.8 \mathrm{~Hz}, 1 \mathrm{H}), 4.21(\mathrm{t}, J=7.0 \mathrm{~Hz}, 2 \mathrm{H}), 1.92-1.86(\mathrm{~m}, 2 \mathrm{H}), 0.99(\mathrm{t}, J=7.4 \mathrm{~Hz}, 3 \mathrm{H}) \mathrm{ppm} ;{ }^{13} \mathrm{C}$ $\mathrm{NMR}\left(100 \mathrm{MHz}, \mathrm{CDCl}_{3}\right): \delta 168.9,154.3,152.3$ 143.3, 138.2, 137.5, 135.8, 135.0, 129.2, 128.9 (×2), 128.5, 127.3 (×2), 126.1, 124.8, 122.9, 122.0, 121.5, 119.1, 112.6, 109.8, 45.2, 23.8, 11.4 ppm; IR (KBr): $v_{\max } 3050,2962,2923,2850,1633,1611,1500,1466,1439,1396,1366,1275$, $1070,954,918,865,807,754,725 \mathrm{~cm}^{-1}$; HRMS (ESI+): $m / z$ calcd for $\mathrm{C}_{25} \mathrm{H}_{22} \mathrm{~N}_{3} \mathrm{~S}[\mathrm{M}+\mathrm{H}]^{+}$ 396.1529; found 396.1528 .

2-(4-Fluoro-3-nitrophenyl)-1-phenyl-1H-benzo[d]imidazole (17): a white solid, mp: $188-189{ }^{\circ} \mathrm{C}$. ${ }^{1} \mathrm{H}$ NMR $\left(400 \mathrm{MHz}, \mathrm{DMSO}-d_{6}\right): \delta 8.23(\mathrm{~d}, J=6.8 \mathrm{~Hz}, 1 \mathrm{H}), 7.84-7.80(\mathrm{~m}, 2 \mathrm{H}), 7.61-7.56(\mathrm{~m}$, $4 \mathrm{H}), 7.49(\mathrm{~d}, J=7.6 \mathrm{~Hz}, 2 \mathrm{H}), 7.35-7.28(\mathrm{~m}, 2 \mathrm{H}), 7.20(\mathrm{~d}, J=7.6 \mathrm{~Hz}, 1 \mathrm{H}) \mathrm{ppm}$; ${ }^{13} \mathrm{C} \mathrm{NMR}$ $\left(100 \mathrm{MHz}, \mathrm{DMSO}-\mathrm{d}_{6}\right): \delta 155.4(\mathrm{~d}, J=263.9 \mathrm{~Hz}), 149.2,142.8,137.6,137.1(\mathrm{~d}, J=7.4 \mathrm{~Hz}), 136.8$ $(\mathrm{d}, J=9.4 \mathrm{~Hz}), 136.2,130.8(\times 2), 129.8,128.0(\times 2), 127.5,127.1,124.5,123.6,120.1,119.3(\mathrm{~d}$, $J=21.4 \mathrm{~Hz}), 111.1 \mathrm{ppm} ;{ }^{19} \mathrm{~F}$ NMR $\left(470 \mathrm{MHz}, \mathrm{DMSO}-d_{6}\right): \delta-108.8 \mathrm{ppm}$; IR (KBr): $v_{\max } 3466$, 2955, 2924, 1621, 1594, 1545, 1498, 1478, 1451, 1381, 1347, 1267, 1191, 1120, 1079, 826, 763, $716 \mathrm{~cm}^{-1}$; HRMS (ESI+): $m / z$ calcd for $\mathrm{C}_{19} \mathrm{H}_{13} \mathrm{FN}_{3} \mathrm{O}_{2}[\mathrm{M}+\mathrm{H}]^{+} 334.0986$; found 334.0986.

2-(2-Fluoro-4-nitrophenyl)-1-phenyl-1H-benzo[d]imidazole (18): a yellow solid, mp: $195-196{ }^{\circ} \mathrm{C}$. ${ }^{1} \mathrm{H}$ NMR $\left(400 \mathrm{MHz}, \mathrm{DMSO}-d_{6}\right): \delta 8.17-8.10(\mathrm{~m}, 2 \mathrm{H}), 7.99(\mathrm{t}, J=8.0 \mathrm{~Hz}, 1 \mathrm{H}), 7.86-7.74(\mathrm{~m}$, $1 \mathrm{H}), 7.52-7.46(\mathrm{~m}, 3 \mathrm{H}), 7.40-7.36(\mathrm{~m}, 5 \mathrm{H}) \mathrm{ppm} ;{ }^{13} \mathrm{C}$ NMR $\left(100 \mathrm{MHz}, \mathrm{DMSO}-d_{6}\right): \delta 159.2(\mathrm{~d}$, $J=252.7 \mathrm{~Hz}), 149.7(\mathrm{~d}, J=8.4 \mathrm{~Hz}), 146.4,143.2136 .6,135.9,134.3,130.4(\times 2), 129.3,126.9$ $(\times 2), 125.4(\mathrm{~d}, J=14.6 \mathrm{~Hz}), 124.8,123.7,120.4,120.2,112.3(\mathrm{~d}, J=26.9 \mathrm{~Hz}), 111.2 \mathrm{ppm} ;{ }^{19} \mathrm{~F}$ NMR (470 MHz, DMSO-d $\left.)_{6}\right): \delta-108.9$ ppm; IR (KBr): $v_{\max } 3435,2955,2923,1637,1596,1536$, $1499,1449,1427,1382,1355,1327,1226,1068,886,809,762,745,724 \mathrm{~cm}^{-1}$; HRMS (ESI+): $m / z$ calcd for $\mathrm{C}_{21} \mathrm{H}_{18} \mathrm{~F}_{3} \mathrm{~N}_{2}[\mathrm{M}+\mathrm{H}]^{+}$334.0986; found 334.0985.

2-(4-Methyl-3-nitrophenyl)-1H-benzo[d]imidazole (23): a white solid, mp: $220-221{ }^{\circ} \mathrm{C} .{ }^{1} \mathrm{H}$ NMR $\left(400 \mathrm{MHz}, \mathrm{DMSO}-d_{6}\right): \delta 13.18(\mathrm{~s}, 1 \mathrm{H}), 8.77(\mathrm{~s}, 1 \mathrm{H}), 8.37(\mathrm{~d}, J=6.0 \mathrm{~Hz}, 1 \mathrm{H}), 7.69-7.62(\mathrm{~m}$, $3 \mathrm{H}), 7.24(\mathrm{~s}, 2 \mathrm{H}), 2.58(\mathrm{~s}, 3 \mathrm{H}) \mathrm{ppm} ;{ }^{13} \mathrm{C} \mathrm{NMR}\left(100 \mathrm{MHz}, \mathrm{DMSO}-d_{6}\right): \delta 149.8,149.6,134.7$, 134.1 (×2), $131.1(\times 2), 129.9,123.0,122.4(\times 2), 20.0$ ppm; IR (KBr): $v_{\max } 3057,2956,2923$, $1631,1520,1456,1382,1346,1081,816,745 \mathrm{~cm}^{-1}$; HRMS (ESI+): $m / z$ calcd for $\mathrm{C}_{14} \mathrm{H}_{12} \mathrm{~N}_{3} \mathrm{O}_{2}$ $[\mathrm{M}+\mathrm{H}]^{+}$254.0924; found 254.0921.

2-(2-Chloro-5-nitrophenyl)-1H-benzo[d]imidazole (24): a white solid, mp: $193-194{ }^{\circ} \mathrm{C} .{ }^{1} \mathrm{H}$ NMR (400 MHz, DMSO- $\left.d_{6}\right): \delta 12.98(\mathrm{~s}, 1 \mathrm{H}), 8.74(\mathrm{~d}, J=2.5 \mathrm{~Hz}, 1 \mathrm{H}), 8.32\left(\mathrm{dd}, J_{1}=2.5 \mathrm{~Hz}\right.$, $\left.J_{2}=8.8 \mathrm{~Hz}, 1 \mathrm{H}\right), 7.94(\mathrm{~d}, J=8.8 \mathrm{~Hz}, 1 \mathrm{H}), 7.74(\mathrm{~d}, J=7.6 \mathrm{~Hz}, 1 \mathrm{H}), 7.61(\mathrm{~d}, J=7.6 \mathrm{~Hz}, 1 \mathrm{H})$, 7.29-7.25 (m, 2H) ppm; ${ }^{13} \mathrm{C}$ NMR (100 MHz, DMSO- $\left.d_{6}\right): \delta 147.5,146.9,143.6,138.6,135.3$, $132.7,131.3,126.9,125.8,123.9,122.6,119.9,112.5$ ppm; IR (KBr): $v_{\max } 3573,3466,3180,1645$, 
1624, 1589, 1457, 1428, 1350, 1310, 1295, 1278, 1138, 1047, 911, 883, 827, 766, 737, $711 \mathrm{~cm}^{-1}$; HRMS (ESI+): $m / z$ calcd for $\mathrm{C}_{13} \mathrm{H}_{9} \mathrm{ClN}_{3} \mathrm{O}_{2}[\mathrm{M}+\mathrm{H}]^{+} 274.0378$; found 274.0376.

\section{Conclusions}

In summary, the current research proved that $\mathrm{Co}(\mathrm{acac})_{2}$ could be employed as a highly efficient catalyst for the synthesis of 1,2-disubstituted and 2-substituted benzimidazoles via $\mathrm{Co}(\mathrm{III}) / \mathrm{Co}$ (II)-mediated redox catalysis, featuring low catalyst loading, mild reaction conditions, fast reaction rate, and high product yields. The easy accessibility of inexpensive $\mathrm{Co}(\mathrm{acac})_{2}$ and $\mathrm{H}_{2} \mathrm{O}_{2}$ and no need for heating make this new method highly practical.

Supplementary Materials: The following are available online at https://www.mdpi.com/article/10 .3390 / catal12010059/s1, Figure S1: UV-Vis absorption change of Co(acac) 3 upon addition to benzaldehyde and N-phenyl-o-phenylenediamine; Figures S2-S19: The NMR spectra of new benzimidazoles.

Author Contributions: S.G. designed the experiments; R.Z., W.X., H.Z. and T.Z. performed the experiments and analyzed the data; Q.S. wrote the manuscript. All authors have read and agreed to the published version of the manuscript.

Funding: This research was funded by National Natural Science Foundation of China (21961013).

Data Availability Statement: Not applicable.

Conflicts of Interest: The authors declare no conflict of interest.

\section{References}

1. Bansal, Y.; Silakari, O. The therapeutic journey of benzimidazoles: A review. Bioorg. Med. Chem. 2012, 20, 6208-6236. [CrossRef]

2. Aili, D.; Yang, J.; Jankova, K.; Henkensmeier, D.; Li, Q. From polybenzimidazoles to polybenzimidazoliums and polybenzimidazolides. J. Mater. Chem. A 2020, 8, 12854-12886. [CrossRef]

3. Keri, R.S.; Hiremathad, A.; Budagumpi, S.; Nagaraja, B.M. Comprehensive review in current developments of benzimidazolebased medicinal chemistry. Chem. Biol. Drug Des. 2015, 86, 19-65. [CrossRef]

4. Sreerama, R.; Barnali, M.; Balamurali, M.M.; Chanda, K. Synthesis and medicinal applications of benzimidazoles: An overview. Curr. Org. Synth. 2017, 14, 40-60.

5. Yadav, G.; Ganguly, S. Structure activity relationship (SAR) study of benzimidazole scaffold for different biological activities: A mini-review. Eur. J. Med. Chem. 2015, 46, 419-443. [CrossRef]

6. Vasava, M.S.; Bhoi, M.N.; Rathwa, S.K.; Jethava, D.J.; Acharya, P.T.; Patel, D.B.; Patel, H.D. Benzimidazole: A milestone in the field of medicinal chemistry. Mini Rev. Med. Chem. 2020, 20, 532-565. [CrossRef]

7. Bai, Y.-B.; Zhang, A.-L.; Tang, J.-J.; Gao, J.-M. Synthesis and antifungal activity of 2-chloromethyl-1H-benzimidazole derivatives against phytopathogenic fungi in vitro. J. Agric. Food Chem. 2013, 61, 2789-2795. [CrossRef]

8. Ballari, M.S.; Cano, N.H.; Lopez, A.G.; Wunderlin, D.A.; Feresín, G.E.; Santiago, A.N. Green synthesis of potential antifungal agents: 2-Benzyl substituted thiobenzoazoles. J. Agric. Food Chem. 2017, 65, 10325-10331. [CrossRef]

9. Carvalho, L.C.R.; Fernandes, E.; Marques, M.M.B. Developments towards regioselective synthesis of 1,2-disubstituted benzimidazoles. Chem. Eur. J. 2011, 17, 12544-12555. [CrossRef]

10. Faheem, M.; Rathaur, A.; Pandey, A.; Singh, K.V.; Tiwari, A.K. A review on the modern synthetic approach of benzimidazole candidate. ChemistrySelect 2020, 5, 3981-3994. [CrossRef]

11. Mamedov, V.A.; Zhukova, N.A. Recent developments towards synthesis of (het)arylbenzimidazoles. Synthesis 2021, 53, 1849-1878. [CrossRef]

12. Itoh, T.; Nagata, K.; Ishikawa, H.; Ohsawa, A. Synthesis of 2-arylbenzothiazoles and imidazoles using scandium triflate as a catalyst for both a ring closing and an oxidation steps. Heterocycles 2004, 63, 2769-2783. [CrossRef]

13. Nagawade, R.R.; Shinde, D.B. Zirconyl(IV) chloride-promoted synthesis of benzimidazole derivatives. Russ. J. Org. Chem. 2006, 42, 453-454. [CrossRef]

14. Shen, M.-G.; Cai, C. Ytterbium perfluorooctanesulfonates catalyzed synthesis of benzimidazole derivatives in fluorous solvents. J. Fluor. Chem. 2007, 128, 232-235. [CrossRef]

15. Dhakshinamoorthy, A.; Kanagaraj, K.; Pitchumani, K. Zn ${ }^{2+}-\mathrm{K} 10$-clay (clayzic) as an efficient water-tolerant, solid acid catalyst for the synthesis of benzimidazoles and quinoxalines at room temperature. Tetrahedron Lett. 2011, 52, 69-73. [CrossRef]

16. Jayabharathi, J.; Thanikachalam, V.; Jayamoorthy, K. Synthesis of some fluorescent benzimidazole derivatives using cobalt(II) hydroxide as highly efficient catalyst-spectral and physico-chemical studies and ESIPT process. Photochem. Photobiol. Sci. 2013, 12, 1761-1773. [CrossRef]

17. Martins, G.M.; Puccinelli, T.; Gariani, R.A.; Xavier, F.R.; Silveira, C.C.; Mendes, S.R. Facile and efficient aerobic one-pot synthesis of benzimidazoles using $\mathrm{Ce}\left(\mathrm{NO}_{3}\right)_{3} \cdot 6 \mathrm{H}_{2} \mathrm{O}$ as promoter. Tetrahedron Lett. 2017, 58, 1969-1972. [CrossRef] 
18. Kommi, D.N.; Jadhavar, P.S.; Kumar, D.; Chakraborti, A.K. "All-water" one-pot diverse synthesis of 1,2-disubstituted benzimidazoles: Hydrogen bond driven synergistic electrophile-nucleophile dual activation by water. Green Chem. 2013, 15, 798-810. [CrossRef]

19. Peng, X.-C.; Gong, S.-S.; Zeng, D.-Y.; Duo, S.-W.; Sun, Q. Activated carbon supported hafnium(IV) chloride as an efficient, recyclable, and facile removable catalyst for expeditious parallel synthesis of benzimidazoles. Catalysts 2020, 10, 436. [CrossRef]

20. Bonacci, S.; Iriti, G.; Mancuso, S.; Novelli, P.; Paonessa, R.; Tallarico, S.; Nardi, M. Montmorillonite K10: An efficient organoheterogeneous catalyst for synthesis of benzimidazole derivatives. Catalysts 2020, 10, 845. [CrossRef]

21. Gioia, M.L.D.; Cassano, R.; Costanzo, P.; Cano, N.H.; Maiuolo, L.; Nardi, M.; Nicoletta, F.P.; Oliverio, M.; Procopio, A. Green synthesis of privileged benzimidazole scaffolds using active deep eutectic solvent. Molecules 2019, 24, 2885. [CrossRef]

22. Beaulieu, P.L.; Haché, B.; Moos, E.V. A practical Oxone ${ }^{\circledR}$-mediated, high-throughput, solution-phase synthesis of benzimidazoles from 1,2-phenylenediamines and aldehydes and its application to preparative scale synthesis. Synthesis 2003, 11, 1683-1692. [CrossRef]

23. Verner, E.; Katz, B.A.; Spencer, J.R.; Allen, D.; Hataye, J.; Hruzewicz, W.; Hui, H.C.; Kolesnikov, A.; Li, Y.; Luong, C.; et al. Development of serine protease inhibitors displaying a multicentered short $(<2.3 \AA)$ hydrogen bond binding mode: Inhibitors of urokinase-type plasminogen activator and factor Xa. J. Med. Chem. 2001, 44, 2753-2771. [CrossRef]

24. Du, L.-H.; Wang, Y.-G. A rapid and efficient synthesis of benzimidazoles using hypervalent iodine as oxidant. Synthesis 2007, 5, 675-678. [CrossRef]

25. Hu, Z.; Zhao, T.; Wang, M.; Wu, J.; Yu, W.; Chang, J. I 2 -mediated Intramolecular C-H amidation for the synthesis of $N$-substituted benzimidazoles. J. Org. Chem. 2017, 82, 3152-3158. [CrossRef]

26. Sun, Q.; Wang, C.-J.; Gong, S.-S.; Ai, Y.-J.; Sun, H.-B. $\mathrm{Cp}_{2} \mathrm{ZrCl}_{2}$-catalyzed synthesis of 2-aminovinyl benzimidazoles under microwave conditions. Chin. Chem. Lett. 2015, 26, 297-300. [CrossRef]

27. Alapati, M.L.P.R.; Abburi, S.R.; Mukkamala, S.B.; Rao, M.K. A simple and efficient one-pot synthesis of 2-substituted benzimidazoles from $\theta$-diaminoarene and aryl aldehydes. Synth. Commun. 2015, 45, 2436-2443. [CrossRef]

28. Bahrami, K.; Khodaei, M.M.; Naali, F. Mild and highly efficient method for the synthesis of 2-arylbenzimidazoles and 2arylbenzothiazoles. J. Org. Chem. 2008, 73, 6835-6837. [CrossRef]

29. Nasr-Esfahani, M.; Mohammadpoor-Baltork, I.; Khosropour, A.R.; Moghadam, M.; Mirkhani, V.; Tangestaninejad, S. Synthesis and characterization of $\mathrm{Cu}(\mathrm{II})$-containing nanosilica triazine dendrimer: A recyclable nanocomposite material for the synthesis of benzimidazoles, benzothiazoles, bisbenzimidazoles and bisbenzothiazoles. J. Mol. Catal. A Chem. 2013, 379, 243-254. [CrossRef]

30. Roy, S.; Banerjee, B.; Salam, N.; Bhaumik, A.; Islam, S.M. Mesoporous titania-iron(III) oxide with nanoscale porosity and high catalytic activity for the synthesis of $\beta$-Aminoalcohols and benzimidazole derivatives. Chem CatChem 2015, 7, $2689-2697$. [CrossRef]

31. Dandia, A.; Parewa, V.; Rathore, K.S. Synthesis and characterization of CdS and Mn doped CdS nanoparticles and their catalytic application for chemoselective synthesis of benzimidazoles and benzothiazoles in aqueous medium. Catal. Commun. 2012, 28, 90-94. [CrossRef]

32. Bai, G.; Lan, X.; Liu, X.; Liu, C.; Shi, L.; Chen, Q.; Chen, G. An ammonium molybdate deposited amorphous silica coated iron oxide magnetic core-shell nanocomposite for the efficient synthesis of 2-benzimidazoles using hydrogen peroxide. Green Chem. 2014, 16, 3160-3168. [CrossRef]

33. Karimian, A.; Kakhki, R.M.; Beidokhti, H.K. Magnetic Co-doped $\mathrm{NiFe}_{2} \mathrm{O}_{4}$ nanocomposite: A heterogeneous and recyclable catalyst for the one-pot synthesis of benzimidazoles, benzoxazoles andbenzothiazoles under solvent-free conditions. J. Chin. Chem. Soc. 2017, 64, 1316-1325. [CrossRef]

34. Xiong, W.-L.; Peng, X.-C.; Zhong, R.-Y.; Zheng, J.; Duo, S.; Gong, S.-S.; Sun, H.-B.; Sun, Q. Construction of a clock catalytic system: Highly efficient and self-Indicating synthesis of benzoheterocycles at ambient temperature. Asian J. Org. Chem. 2021, 10, 3321-3327. [CrossRef]

35. Cano, N.H.; Uranga, J.G.; Nardi, M.; Procopio, A.; Wunderlin, D.A.; Santiago, A.N. Selective and eco-friendly procedures for the synthesis of benzimidazole derivatives. The role of the $\mathrm{Er}(\mathrm{OTf})_{3}$ catalyst in the reaction selectivity. Beilstein J. Org. Chem. 2016, 12, 2410-2419. [CrossRef] [PubMed] 